\title{
Strategy of Seaweed Cluster Development in Local Economic Development
}

\author{
Mastur Mujib Ikhsani \\ Universitas Muhammadiyah Purwokerto \\ mastur_mujib@yahoo.co.id
}

\begin{abstract}
The main objective of this research is to determine the strategy of seaweed development in local economic development. The strategy of seaweed cluster development was collected from the stake holders associated with these a weed cluster. This study used primary data gathered from interviews and questionnaires with stake holders. This study also used Analytic Network Process (ANP). Results showed that priority was used in the strategy of seaweed cluster development, it was the strategy of seaweed product marketing management. This was congruent with Brebes District seaweed cluster development-i.e. priority aspects, priority issues, and priority solutions.
\end{abstract}

Keyword: seaweed cluster, strategy, brebes district

\section{INTRODUCTION}

Development is a planned and directed effort to improve the welfare of human life that demands a sociocultural change as a supporter of its success. The national development of Indonesia aims to create a just and prosperous material and spiritual society based on Pancasila(five-pillar ideology), within a unified, sovereign, and united republic of a unitary state of the Indonesian republic, in peaceful, orderly, and dynamic atmosphere, along with the social environment of an independent, friendly, systematic, and peaceful world. Furthermore, the nature of Indonesia's national development means the development of the Indonesian people as a whole and the development of the entire Indonesian community altogether [1].

The enactment of the regional autonomy law No. 22 of 1999, there has been a change of development is classified into four (4) types; the first one is Static Cluster (Sentra) which is a passive cluster, whereas cooperation is only limited to the brotherhood, this has not been developed yet [2]. Second, Beginner Cluster, which is an active cluster and has been grown although still constrained in quantity and quality of production. Third, Dynamic Cluster, it is a cluster which marketing product has successfully reached overseas, and the last one is Advanced Cluster, it is a cluster that has developed cooperation with other various stakeholders involved in its development. paradigm from the development by the center (top down) into the development by the region or local (bottom up) and more participative, where the participation of the community in development is indispensable. In addition, local governments are given the authority to empower and utilize the potential of human and natural resources for the welfare of local communities.

Regional economic development is a process that includes the establishment of new institutions, the development of alternative industries to improve the capacity of existing labor to produce better products and services, market identification, knowledge transfer, and new companies development. This aims to increase the number and type of employment opportunities for local communities. In an effort to achieve these goals, local governments and their communities must take local development initiatives. Therefore, local governments, with the support of community participation, should be able to assess the potential of existing and necessary resources to design and build the regional economy [3].

Local Economic Development (LED) program is a regional economic policy which generally focuses on leverage sectors that can give a strong influence on the improvement of regional economic system. LED is a concept of economic development based on the empowerment of local resources in a community (human resources, natural resources, and institutional resources) or a process where government, private, and local communities work together to shape better conditions for economic growth and job creation.

Cluster-based product development is the core of local economic development (LED) activities in Central Java, not least in Brebes District. The development of cluster flagship product it self

In its development, the main problem of Seaweed Cluster is the absence of innovation in processing seaweed into processed products. Communities who cultivate seaweed, tend to sell it in the form of dried seaweed, whereas if the selling is in the form of processed products, its value (selling price) will increase. Seaweed as a product is not that popular in the Brebes District in comparison to salted egg and onion, whereas seaweed itself has been developed since 2006 and the production and value of its production from year to year experienced an increase and development. In addition, the production of seaweed in Brebes District 
has not been able to meet the demand of national seaweed that has been proclaimed as the largest producer of seaweed in the world. In that case, a strategy in the development of seaweed clusters in Brebes District to spur Seaweed Cluster is needed, so that later can meet the national needs and also can innovate the processed products from seaweed.

\section{METHODS}

Technical analysis used in this research is Analytic Networking Process (ANP). This analysis is to determine the policy strategy for the development of Seaweed Clusters in Brebes District where variables are incorporated into a hierarchical order. Also, it gives numerical consideration to subjective considerations about the relative importance of variables and synthesizes the various considerations for determining which variables have the highest relative priority. The earliest step in the use of network analysis process is to break down the problems into its elements and set part of the elements into the hierarchy [4].

When the assessment is done for a pair, the reciprocity value is automatically set to the inverse ratio in the matrix. After pairwise comparison is complete, the vector corresponding to the maximum eigenvalue of the constructed matrix is calculated and the priority vector is obtained. The priority value is found by normalizing this vector. In the assessment process, problems can occur in consistency of pairwise comparisons. The consistency ratio provides a numerical assessment of how likely this evaluation may be inconsistent. If the calculated ratio is less than 0.10 , the consistency is considered satisfactory

Stabilization is achieved when all the columns in the corresponding supermatrix for each node have the same value. These steps are performed in Super Decisions software, which is a software package developed for ANP applications. For each sub-network, the same procedure is applied and the alternatives are ranked.

To facilitate ANP analysis, this study used software assistance, Super Decisions 2.0.8.

\section{DISCUSSION}

The problems in the development of seaweed clusters in Brebes District can be divided into 5 aspects, consisting of: economic and market aspect; regulation aspect; institutional aspect; culture and human resources aspect; and infrastructure aspects. The whole clusters are grouped into cluster problems, solutions and strategies.

Economic and Market Issues.

(1) The absence of innovation in processed products of seaweed is foundin the seaweed farmers who mostly sold seaweed in the form of raw materials (dried seaweed). (2) Financial is hard to get, especially lowinterest capital. (3) The marketing of seaweed processed products is still local because of the amount processed and the processing itself is still limited and there is no home industry that specializes in seaweed processing.

\section{Regulation Issues}

(1) The regulation has not been synergized with what is needed by the seaweed farmers in Brebes District. (2) Cluster program is not optimal yet because there is no regular evaluation and assistance. (3) The absence of support programs that can support the success of seaweed clusters in Brebes District.

Institutional Issues

(1) The cooperatives that should be able to be a container and institution for seaweed cluster are not formed yet. (2) Stakeholders' lack of synergy related to seaweed clusters as they maintain their own egoism. (3) The community is not yet empowered, this is indicated by the majority of society, especially family members who do not work should be able to take time to process the processed seaweed when the home industry is already formed.

Culture and HR Problems

(1) There is no awareness to improve seaweed business results, both in terms of quality and quantity. (2) The human resource education is low that affects the community level of knowledge and mindset towards seaweed cultivation. (3) There is an absence of awareness to the importance of farmer organization, as seaweed farmers consider it having no significant effect to their business.

Infrastructure Problems

(1) In Brebes District, seaweed center business units are still in small scalecompared to the potential land/pond that has not been utilized for seaweed cultivation. (2) The number of shelter (warehouses) of seaweed is limitedduring its harvest time. (3) The damage of facilities and infrastructure, such as production road, pond embankment, and water channelhas a direct impact on the results of seaweed farming in Brebes District.

Based on the results of interviews and analysis of the authors, a variety of alternative solutions to solve problems in the development of seaweed clusters in Brebes District are:

Economic and Market Solutions

(1) To design innovation in processed seaweed so that farmers can get added value from processed seaweed instead of selling it in the form of raw material (dried seaweed). (2) To provide low-interest capital to increase production, so that seaweed farmers can still maintain the sustainability of their business. (3) To expand the marketing of seaweed processed products not only in the local, so it is expected to be excellent products from Brebes District beside salted egg and red onion.

Regulation Solutions

(1) Regulation synergies expected thatregulations or policies issued by the government would be in accordance with the needs and conditions in the field (seaweed clusters). (2) Regular and periodical optimalization and evaluation of the cluster program as well as intensive assistance are established to support the success and sustainability of seaweed 
clusters in Brebes District. (3) Initiation program is established to support the success of seaweed clusters in Brebes District.

Institutional Solutions

(1) To optimize and develop cooperatives as a room and institution for seaweed clusters in Brebes District. (2) To increase the synergy of stakeholders so as to have one common goal to develop seaweed clusters for their sustainability and continuity. (3) Government is encouraged to empower the community through the guidance and facilitation by enabling the helpless community, especially in seaweed cultivation.

Culture and HR Solutions

(1) To advocate the importance of improving seaweed business results to change the mindset of farmers who tend to be satisfied with the results obtained. (2) To increase awareness of the importance of education so that farmers can add insight and knowledge related to seaweed farming business. (3) To instigate the importance of organizing and cooperating that is useful for the community, especially related to institutions that can accommodate, conform, and make forum to exchange ideas, share, and ask questions about the development of seaweed cultivation business.

Infrastructure Solutions

(1) To add seaweed center business units by utilizing potential and untapped farms / ponds for seaweed cultivation. (2) To provide facilities and shelters of production, so that later seaweed harvest can be accommodated in temporary shelters (warehouses) before being sold or processed. (3) To improve the supporting facilities and infrastructure as an effort to facilitate the continuity and sustainability of seaweed farming business in Brebes District.

Based on the results of interviews and analysis of the author, it can be obtained some strategies proposed in the development of seaweed clusters in Brebes District, such as: 1.Marketing Management Strategy, 2.Optimizing Government's Role to Seaweed Clusters, 3.Formation and Optimization of Seaweed Cluster Institution, 4.Socialization and Training to Improve the Quality of Human Resources, 5.Addition and Improvement of Supporting Facilities and Seaweed Clusters

\section{CONCLUSION}

Based on the priority aspect, the main focus in the development of seaweed clusters in Brebes District are economy and market aspects, second aspect is infrastructure, and the third is culture and human resources. Based on stakeholders who are the respondents of this research consisting of experts, practitioners, and regulatoion makers express different voices related to the priority aspects in the development of seaweed clusters in Brebes District. Only regulation makerswho have the same outcome as the total priority aspect. Meanwhile, according to the priority experts, the main aspect is culture and human resources; wheareas according to the priority practitioners, the main aspect is infrastructure.
The main problems that occured in the development of seaweed clusters in Brebes District are the first one, marketing of seaweed processed products are still local; the second,it is the absence of innovation of seaweed processed products; third,it is the destruction of supporting facilities and clusters of seaweed clusters. The stakeholders consisting of experts, practitioners and regulators, declared the same voice related to the priority problems in the development of seaweed clusters in Brebes District.

The result of the first priority solution is the widespread marketing of seaweed product, the second is the innovation of the processed products of seaweed, and the third is the improvement of supporting facilities for seaweed clusters. According to the stakeholders consisting of experts, practitioners, and regulation makers, only experts differ in their views, they assert that the first problem of seaweed product is innovation, the second is the marketing of seaweed products, and the third is the improvement of facilities and infrastructure. As for practitioners and regulation makers, they have the same statement as the results of the total priority problems in the development of seaweed clusters in Brebes District.

Based on the calculation of Analytic Network Process (ANP) using super decision software 1.6.0, the result of priority of the first alternative strategy is product marketing management strategy, the second is the addition and improvement of supporting facilities for seaweed cluster, and the third is socialization and training to improve the quality of human resources.

The marketing management of seaweed products is seen as the most appropriate strategy in the development of seaweed clusters in Brebes District. This is in line with priority aspects, priority problems, and solution priorities in the development of seaweed clusters in Brebes District. Seaweed product marketing strategy is expected to solve one of the problems that occur in the development of seaweed clusters in Brebes District through the innovation of processed seaweed products and its widespread marketing so that it is expected to become one of the superior seaweed products of Brebes District.

\section{REFERENCES}

[1] Widodo, T. Perencanaan Pembangunan: Aplikasi Komputer (Era Otonomi Daerah). Yogyakarta: UPP STIM YKPN.(2006).

[2] Kuncoro, M. Otonomi dan Pembangunan Daerah: Reformasi, Perencanaan. Strategi, dan Peluang.(2004).

[3] Kuncoro, M. Perencanaan daerah: bagaimana membangun ekonomi lokal, kota, dan kawasan?. Salemba Empat.(2012).

[4] Saaty, T. L., \& Vargas, L. G. Models, methods, concepts \& applications of the analytic hierarchy process (Vol. 175). Springer Science \& Business Media.(2012). 